\title{
Regulative theory of temperament versus affective temperaments measured by the temperament evaluation of Memphis, Pisa, Paris and San Diego Auto-questionnaire (TEMPS-A): a study in a non-clinical Polish sample
}

\author{
Wtodzimierz Oniszczenko ${ }^{1 \cdot A, B, C, D, E, G}$, Ewa Stanistawiak ${ }^{2 \cdot B, D, E, F}$, \\ Daria Dembińska-Krajewska ${ }^{3 \cdot B, D, E, F}$, Janusz Rybakowski $i^{3 \cdot A, D, E}$ \\ 1: Faculty of Psychology, University of Warsaw, Warsaw, Poland \\ 2: Faculty of Psychology, University of Finance and Management, Warsaw, Poland \\ 3: Department of Adult Psychiatry, Poznan University of Medical Sciences, Poznan, Poland
}

\section{BACKGROUND}

This study investigates the relationship between temperament traits postulated by Strelau's regulative theory of temperament (RTT) and Akiskal's affective temperaments. This study represents the first attempt to compare these two concepts in a non-clinical Polish sample.

\section{PARTICIPANTS AND PROCEDURE}

The study involved 615 healthy Caucasian adults (395 women and 220 men) aged from 17 to 69 years $(M=30.79, S D=9.69)$. Temperament traits postulated by the RTT were assessed with the Formal Characteristics of Behaviour-Temperament Inventory. The Polish version of the Temperament Evaluation of Memphis, Pisa, Paris and San Diego Auto-questionnaire (TEMPS-A) was used to assess affective temperaments (depressive, cyclothymic, hyperthymic, irritable and anxious).

\section{RESULTS}

Emotional reactivity and perseveration (RTT) positively correlated with anxious, cyclothymic, depressive and irri- table temperaments (TEMPS-A), predicting from 2\% (irritable temperament) to $24 \%$ (anxious temperaments) of the variance in the affective temperaments. Hyperthymic temperament (TEMPS-A) positively correlated with briskness, sensory sensitivity, endurance and activity (RTT). Activity was the best predictor of hyperthymic temperament, accounting for $25 \%$ of the variance. TEMPS-A scores showed that women were more depressive, cyclothymic and anxious and less hyperthymic than men.

\section{CONCLUSIONS}

These results suggest that two RTT traits, emotional reactivity and perseveration, may be related to all the affective temperaments of TEMPS-A, except hyperthymic temperament, which is most likely linked to the RTT activity trait.

\section{KEY WORDS}

temperament; healthy adults; personality inventory

CORResponding Author - Prof. Włodzimierz Oniszczenko, Faculty of Psychology, University of Warsaw, 5/7 Stawki Str., 00-183 Warsaw, Poland, e-mail: wlodek@psych.uw.edu.pl

AUthors' CONTRIBUtion - A: Study design - B: Data collection · C: Statistical analysis - D: Data interpretation

E: Manuscript preparation · F: Literature search · G: Funds collection

to Cite this ARTICLE - Oniszczenko, W., Stanisławiak, E., Dembińska-Krajewska, D., \& Rybakowski, J. (2017). Regulative theory of temperament versus affective temperaments measured by the temperament evaluation of Memphis,

Pisa, Paris and San Diego Auto-questionnaire (TEMPS-A): a study in a non-clinical Polish sample. Current Issues in

Personality Psychology, 5(2), 73-82.

RECEIVED 26.09.2016 · REVIEWED 18.12.2016 - ACCEPTED 21.01.2017 • PUBLISHED 20.02.2017 


\section{BACKGROUND}

The regulative theory of temperament (RTT) formulated by Strelau (1998) emphasises the role of temperament in the regulation of people's relations with their environment. According to the RTT, temperament refers to basic, relatively stable, individual traits. These traits are manifested in the energetic (response intensity) and temporal characteristics (speed, tempo and mobility) of behaviour. Importantly, temperament is present at birth, and the biological mechanisms linked to these traits work together to regulate the individual level of arousal during one's lifespan. Regulative theory of temperament traits are present prior to stressful or traumatic events and influence the state of stress as well as its consequences (Strelau, 2008).

Six temperament traits are postulated by the RTT (Strelau, 1996): briskness (BR), the tendency to respond swiftly, to maintain a high tempo of activity, to switch easily from one behaviour to another and to respond adequately to changes in the environment; perseveration (PE), the tendency to maintain and repeat behaviours after the situation that evoked these behaviours has changed; sensory sensitivity (SS), the capacity to respond to sensory stimuli of low stimulating value; emotional reactivity (ER), the tendency to respond intensely to emotogenic stimuli, manifested as high emotional sensitivity and low emotional resistance; endurance (EN), the capacity to respond adequately in situations requiring prolonged or highly stimulating activity and/or in conditions of high external stimulation; and activity (AC), the tendency to engage in behaviours that are themselves highly stimulating or provide highly stimulating environmental input.

Kandler et al. (2012) showed phenotypic links between RTT and Big Five personality traits that could be attributed mainly to genetic correlations, especially between ER and PE and neuroticism, as well as between BR, EN, AC and extraversion. Furthermore, Hornowska (2011) showed the following associations between Cloninger's psychobiological model of personality dimensions and Strelau's RTT traits: strong positive correlations between harm avoidance (HA) and $\mathrm{ER}$ and $\mathrm{PE}$, and negative correlations between $\mathrm{HA}$ and BR, EN and AC.

According to the RTT, a specific temperament trait or constellation (a so-called temperamental risk factor) increases the risk of pathology, either itself or via interaction with intensive, prolonged or frequent environmental factors (Strelau, 2008). The biological mechanisms underlying these traits interact to regulate the individual level of arousal, in terms of both duration and intensity. This may lead to various consequences such as behaviour disorders or psychological and somatic ill health (Strelau, 1998). It has been shown, for example, that ER positively correlates with anxiety disorder in cancer patients (Oniszczenko \& Laskowska, 2014), HIV-positive individuals (Rzeszutek, Oniszczenko, \& Firląg-Burkacka, 2012) and patients suffering from chronic pain (Rzeszutek, Oniszczenko, Schier, Biernat-Kałuża, \& Gasik, 2015). High levels of ER and PE and low levels of BR, EN and $\mathrm{AC}$ were found in patients diagnosed as bipolar (Strelau, 2008). Oniszczenko, Dragan, Chmura and Lisik (2015a) found a high level of PE and low levels of BR, EN and AC in clinically obese patients. On the other hand, a high level of ER and low levels of BR, SS, EN and AC were found in alcohol-dependent men (Oniszczenko, Rybakowski, Dragan, Grzywacz, \& Samochowiec, 2015b). Fruehstorfer, Veronie, Cremeans-Smith and Newberry (2012) showed that PE can predict the occurrence of psychometrically measured somatic anxiety.

Previously conducted twin studies have demonstrated the heritability of RTT traits in Polish and German populations (Oniszczenko et al., 2003). More recent studies point to the significant association between ER and the DRD4 gene (Oniszczenko \& Dragan, 2005), SS and the DAT1 gene (Dragan, Oniszczenko, Czerski, \& Dmitrzak-Węglarz, 2012; Oniszczenko \& Dragan, 2012) and AC and EN and the 5-HTTLPR gene (Dragan \& Oniszczenko, 2005, 2006). Oniszczenko and Dragan (2006) have also shown that the 5-HTT polymorphism is associated with the harmonised structure of RTT traits, showing high potential for stimulation processing (high levels of BR, $\mathrm{SS}, \mathrm{EN}$, and $\mathrm{AC}$, and low levels of ER and PE).

The Temperament Evaluation of Memphis, Pisa, Paris and San Diego Auto-questionnaire (TEMPS-A) measures affective temperament types (depressive, cyclothymic, hyperthymic, irritable and anxious) and plays a definitive role in determining the predisposition to affective disorders (Akiskal \& Akiskal, 2005; DeGeorge, Walsh, Barrantes-Vidal, \& Kwapil, 2014). Kawamura et al. (2010) showed that affective temperaments exhibit good long-term stability and may be considered as stable traits. Several authors have suggested molecular genetic associations between serotonergic gene polymorphisms and depressive, cyclothymic, irritable and anxious temperaments as well as between dopaminergic gene polymorphisms and hyperthymic temperament (Rihmer, Akiskal, Rihmer, \& Akiskal, 2010; Vázquez \& Gonda, 2013; see also Borkowska et al., 2015). Temperamental dimensions of the TEMPS-A were also associated with polymorphisms of some circadian clock genes (Rybakowski et al., 2014).

In studies performed in Poznań, a positive correlation was found between long-term lithium response and hyperthymic temperament as per the TEMPS-A (Rybakowski, Dembińska, Kliwicki, Akiskal, \& Akiskal, 2013) and a possible decrease in cyclothymic and irritable temperaments with long-term 
lithium treatment (Dembińska-Krajewska \& Rybakowski, 2015). Female patients with co-morbid bulimia and bipolarity reported significantly higher scores of cyclothymic and irritable temperaments than female patients with both "pure" bipolar disorder and "pure" bulimia (Rybakowski, Kamińska, Charytonik, Akiskal, \& Akiskal, 2014). Significantly higher scores of hyperthymic temperament were reported among individuals engaging in extreme and/or high risk sports (Siwek et al., 2015).

The concept of affective temperaments is clinically useful not only in the case of mood disorders but also in patients with rheumatoid arthritis (Rezvani et al., 2014), obesity (Amann et al., 2009), HIV (Pompili et al., 2013) and alcohol and/or opiate dependence (Khazaal et al., 2013). We believe that it is important that affective temperaments encompass healthy personality traits (Rovai et al., 2013) and have both universal and culturally specific characteristics, as proposed by Vázquez, Tondo, Mazzarini, and Gonda (2012).

Akiskal's affective temperament is associated with domains of normal personality, as described by McCrae and Costa's five-factor model of personality (Blöink, Briegera, Akiskal, \& Marneros, 2005; Kwapil et al., 2013; Rózsa et al., 2008) and Cloninger's psychobiological model of temperament and character (Harnic et al., 2013; Ristić-Ignjatović et al., 2014; Rózsa et al., 2008; Akiskal et al., 2005). Studies confirm the similarity between the concept of affective temperaments and other models of personality, including normally functioning personality (temperament).

The concept of affective temperaments and the RTT can be considered convergent. Both concepts postulate that temperament dimensions stabilise over time and a dominant affective temperament or extreme RTT trait levels may predispose to psychopathology. Affective temperaments and RTT traits overlap with the five-factor model of personality as well as with Cloninger's psychobiological model of personality dimensions. Finally, affective temperaments and some of the RTT traits are associated with the same genetic polymorphisms as candidate genes associated with dopaminergic and serotonergic systems.

The main goal of our study was to investigate and evaluate the relationship between temperament traits postulated by the RTT and affective temperaments as measured by the TEMPS-A in the nonclinical population.

We hypothesized that: (a) emotional reactivity and perseveration would be positively correlated with depressive, cyclothymic, irritable and anxious temperaments, while briskness, endurance, and activity would be negatively correlated with depressive, cyclothymic, irritable and anxious temperaments; (b) hyperthymic temperament would be negatively correlated with emotional reactivity and perseverance, while the correlation between hyperthymic temperament and briskness, endurance and activity would be positive. The role of sensory sensibility as a predictor of affective temperaments is quite unclear. Thus, we did not create a hypothesis for this variable.

\section{PARTICIPANTS AND PROCEDURE}

\section{PARTICIPANTS}

The sample consisted of 615 healthy Caucasian adults (395 women and 220 men) recruited from a nonclinical population. Participants' ages ranged from 17 to $69(M=30.79, S D=9.69)$. In terms of education levels, 390 participants had received higher education, 195 participants secondary education and 19 participants primary education (11 participants did not provide any information about their education). All self-report questionnaires were administered in a standard manner.

The study was anonymous, and participation was voluntary. Informed consent was obtained from all participants before they were included in the study, and the participants did not receive any compensation. The research project was accepted by the local Ethics Commission at the Faculty of Psychology, University of Warsaw.

\section{MEASURES}

The Polish version of the TEMPS-A scale was used for the assessment of affective temperaments (Borkowska et al., 2010). The TEMPS-A is a self-report instrument comprising 110 items (109 for men) with a yes-no response format (Akiskal, Akiskal, Haykal, Manning, \& Connor, 2005; Dembińska-Krajewska \& Rybakowski, 2014). The TEMPS-A is composed of five scales (Cronbach $\alpha$ for the Polish version are given in parentheses): depressive (.70), cyclothymic (.77), hyperthymic (.75), irritable (.76) and anxious (.83).

The RTT temperament traits were measured with the Formal Characteristics of Behaviour-Temperament Inventory (FCB-TI; Strelau \& Zawadzki, 1995). This questionnaire has 120 items with a yes-no response format, and 20 items per scale. The FCB-TI consists of the following scales (Cronbach $\alpha$ are given in parentheses): briskness (.77), perseveration (.79), sensory sensitivity (.73), emotional reactivity (.83), endurance (.85) and activity (.84).

\section{STATISTICAL ANALYSIS}

Statistical analysis was performed using IBM SPSS Statistics 22 (IBM Corp., 2013). The values for skewness and kurtosis in the studied sample were acceptable in order to prove a normal distribution. According to Tabachnick and Fidell (2013) the acceptable 
range for skewness or kurtosis is below +1.5 and above -1.5 . The $t$-test for independent samples was used to test the significance of differences between women and men. Relationships among variables were examined with Pearson's product-moment correlation coefficient. Multiple linear regression analysis was used to estimate whether RTT temperament traits could serve as predictors of TEMPS-A affective temperaments.

\section{RESULTS}

Table 1 shows the means and standard deviations as well as skewness and kurtosis values for affective temperaments and RTT temperament traits for the whole sample.
Table 2 presents the correlations among age, affective temperaments and RTT temperament traits in the whole sample. A positive correlation was found for age and BR. A negative correlation was found for age and cyclothymic and irritable temperaments as well as for age and PE and AC. Depressive temperament was positively correlated with $\mathrm{PE}$ and ER and negatively with BR, EN and AC. Cyclothymic temperament was positively correlated with $\mathrm{PE}$ and ER and negatively correlated with BR and EN. Hyperthymic temperament was positively correlated with $\mathrm{BR}, \mathrm{SS}, \mathrm{EN}$ and AC and negatively correlated with $\mathrm{PE}$ and ER. Irritable temperament was positively correlated with PE and ER and negatively correlated with BR and EN. Anxious temperament was positively correlated with PE and ER and negatively correlated with BR, EN and AC.

Table 1

Descriptive statistics for the TEMPS-A and FCB-TI scales

\begin{tabular}{lcccc}
\hline Temperament scale & Range observed & $M(S D)$ & Skewness & Kurtosis \\
\hline TEMPS-A & & & & 0.79 \\
Depressive & $0.00-0.95$ & $0.34(0.16)$ & 0.51 & -0.59 \\
Cyclothymic & $0.00-0.95$ & $0.33(0.21)$ & -0.15 & -0.61 \\
Hyperthymic & $0.00-1.00$ & $0.50(0.20)$ & 1.05 & 1.03 \\
Irritable & $0.00-0.95$ & $0.21(0.18)$ & 0.77 & 0.02 \\
Anxious & $0.00-1.00$ & $0.28(0.20)$ & & 0.41 \\
FCB-TI & & & -0.79 & -0.40 \\
Briskness & $0-20$ & $14.92(3.72)$ & -0.37 & 0.42 \\
Perseveration & $1-20$ & $12.39(4.12)$ & -0.77 & -0.90 \\
Sensory sensitivity & $2-20$ & $14.71(3.45)$ & -0.05 & -0.81 \\
Emotional reactivity & $0-20$ & $9.89(4.99)$ & 0.05 & -0.81 \\
Endurance & $0-20$ & $10.07(4.85)$ & 0.20 & \\
Activity & $0-20$ & $8.90(4.78)$ & & \\
\hline
\end{tabular}

Table 2

Pearson's $r$ correlations between age, FCB-TI scales and TEMPS-A scales

\begin{tabular}{|c|c|c|c|c|c|c|}
\hline Variable & Age & $\begin{array}{l}\text { TEMPS-A: } \\
\text { Depressive }\end{array}$ & $\begin{array}{c}\text { TEMPS-A: } \\
\text { Cyclothymic }\end{array}$ & $\begin{array}{c}\text { TEMPS-A: } \\
\text { Hyperthymic }\end{array}$ & $\begin{array}{l}\text { TEMPS- A: } \\
\text { Irritable }\end{array}$ & $\begin{array}{c}\text { TEMPS-A: } \\
\text { Anxious }\end{array}$ \\
\hline Age & & .02 & $-.22^{* * *}$ & .04 & $-.16^{* * *}$ & -.01 \\
\hline BR & $.12^{* *}$ & $-.29^{* * *}$ & $-.31^{* * *}$ & $.37^{* * *}$ & $-.17^{* * *}$ & $-.37^{* * *}$ \\
\hline$P E$ & $-.18^{* * *}$ & $.31^{* * *}$ & $.47^{* * *}$ & $-.22^{* * *}$ & $.21^{* * *}$ & $.55^{* * *}$ \\
\hline SS & .07 & $-.09^{*}$ & -.06 & $.14^{* * *}$ & -.07 & -.06 \\
\hline ER & -.03 & $.53^{* * *}$ & $.47^{* * *}$ & $-.49^{* * *}$ & $.25^{* * *}$ & $.64^{* * *}$ \\
\hline EN & .03 & $-.31^{* * *}$ & $-.34^{* * *}$ & $.36^{* * *}$ & $-.15^{* * *}$ & $-.44^{* * *}$ \\
\hline $\mathrm{AC}$ & $-.13^{* *}$ & $-.39 * * *$ & -.03 & $.63^{* * *}$ & -.07 & $-.24^{* * *}$ \\
\hline
\end{tabular}

Note. ${ }^{*} p<.05,{ }^{* *} p<.01,{ }^{* * *} p<.001$. BR - briskness, PE - perseveration, SS - sensory sensitivity, ER - emotional reactivity, $\mathrm{EN}$ - endurance, $\mathrm{AC}$ - activity. 
Descriptive data about the participants are presented in Table 3 along with differences between the studied groups.

As shown in Table 3, women had higher levels of depressive, cyclothymic and anxious temperaments than men. Men had a higher level of hyperthymic temperament than women. No significant differences were found between the two groups with regard to irritable temperament. Women also showed higher levels of PE, SS and ER as well as a lower level of EN than men. No significant differences were found between the two groups with regard to BR and AC.

To determine the extent to which RTT temperament traits can be considered predictors of affective temperaments, a multiple linear regression analysis was conducted. Each TEMPS-A scale was treated as a dependent variable, and the six RTT traits as independent variables in the analysis. The results of regression analysis are presented in Table 4.

From the regression coefficients, two variables were found to be significant predictors of depressive temperament: $\mathrm{ER}(\beta=.47, p<.001)$ and $\mathrm{AC}(\beta=-.22$, $p<.001)$. Standardised $\beta$ coefficients showed that the higher the level of ER and the lower the level of AC, the higher the depressive temperament level. The sum of the squared semi-partial correlations showed that ER and AC accounted for $13 \%$ of the variance in depressive temperament. We also found that four RTT traits were significant predictors of cyclothymic temperament: $\mathrm{BR}(\beta=-.12, p=.004)$, $\mathrm{PE}(\beta=.26$, $p<.001)$, ER $(\beta=.28, p<.001)$ and $\mathrm{AC}(\beta=.15$, $p<.001)$. The higher the levels of PE, ER, and AC and the lower the level of BR, the higher was the cyclothymic temperament level. BR, PE, ER and AC accounted for $18 \%$ of the variance in cyclothymic temperament. Only two RTT traits were found to be significant predictors of hyperthymic temperament: ER $(\beta=-.27$, $p<.001)$ and $\mathrm{AC}(\beta=.50, p<.001)$. The higher the level of AC and the lower the level of ER, the higher was the hyperthymic temperament level. ER and AC accounted for $32 \%$ of the variance in hyperthymic temperament. BR $(\beta=.09, p=.010)$ explained only $0.005 \%$ of the hyperthymic temperament variance. Two RTT traits were significant predictors of irritable temperament: $\mathrm{PE}(\beta=.11, p=.039)$ and $\mathrm{ER}(\beta=.17$, $p=.005)$. The higher the levels of PE and ER, the higher was the irritable temperament level. PE and ER accounted for only $2 \%$ of the variance in irritable temperament. Two RTT traits were found to be significant predictors of anxious temperament: $\mathrm{PE}$ $(\beta=.26, p<.001)$ and $\operatorname{ER}(\beta=.41, p<.001)$. The higher the level of PE and ER, the higher was the anxious temperament level. PE and ER accounted for $24 \%$ of the variance in anxious temperament. $\mathrm{BR}(\beta=-.08$, $p=.036$ ) explains only $0.004 \%$ of the anxious temperament variance.

\section{DISCUSSION}

The purpose of the study was to evaluate the relationship between affective temperaments as measured by TEMPS-A and RTT traits as measured by the FCB-TI. The results obtained in this study seem

Table 3

Gender differences in affective temperaments and FCB-TI temperament traits $(n=613)$

\begin{tabular}{|c|c|c|c|c|c|}
\hline & $\begin{array}{c}\text { Females }(n=395) \\
M(S D)\end{array}$ & $\begin{array}{c}\text { Males }(n=220) \\
M(S D)\end{array}$ & $t$ & $p$ & Cohen's $d$ \\
\hline \multicolumn{6}{|l|}{ TEMPS-A } \\
\hline Depressive & $0.37(0.16)$ & $0.31(0.15)$ & 4.47 & $<.001$ & .39 \\
\hline Cyclothymic & $0.34(0.21)$ & $0.30(0.21)$ & 2.24 & .025 & .19 \\
\hline Hyperthymic & $0.48(0.20)$ & $0.53(0.20)$ & -3.03 & .003 & -.25 \\
\hline Irritable & $0.21(0.17)$ & $0.21(0.19)$ & -0.57 & n.s. & .00 \\
\hline Anxious & $0.32(0.21)$ & $0.20(0.16)$ & 7.41 & $<.001$ & .64 \\
\hline \multicolumn{6}{|l|}{ FCB-TI } \\
\hline Briskness & $14.71(3.79)$ & $15.30(3.56)$ & -1.91 & n.s. & -.16 \\
\hline Perseveration & $13.10(3.98)$ & $11.11(4.08)$ & 5.88 & $<.001$ & .49 \\
\hline Sensory sensitivity & $15.18(3.16)$ & $13.87(3.79)$ & 4.58 & $<.001$ & .37 \\
\hline $\begin{array}{l}\text { Emotional reac- } \\
\text { tivity }\end{array}$ & $11.23(4.74)$ & $7.49(4.52)$ & 9.55 & $<.001$ & .81 \\
\hline Endurance & $9.35(4.74)$ & $11.37(4.79)$ & -5.05 & $<.001$ & -.42 \\
\hline Activity & $8.73(4.71)$ & $9.20(4.90)$ & -1.16 & n.s. & -.10 \\
\hline
\end{tabular}


Table 4

Multiple linear regression analysis of FCB-TI temperament traits as predictors of affective temperaments as measured by the TEMPS-A

\begin{tabular}{|c|c|c|c|c|}
\hline Variable & $B$ & $S E B$ & $\beta$ & Semi-partial Correlations \\
\hline \multicolumn{5}{|l|}{ TEMPS-A: Depressive } \\
\hline Briskness & -.00 & .04 & -.02 & -.02 \\
\hline Perseveration & .00 & .00 & .01 & .01 \\
\hline Sensory sensitivity & -.00 & .00 & -.03 & -.03 \\
\hline Emotional reactivity & .01 & .00 & $.47^{* * *}$ & .30 \\
\hline Endurance & .00 & .00 & .05 & .04 \\
\hline Activity & -.01 & .00 & $-.22^{* * *}$ & -.20 \\
\hline \multicolumn{5}{|l|}{ TEMPS-A: Cyclothymic } \\
\hline Briskness & -.01 & .00 & $-.12^{* *}$ & -.10 \\
\hline Perseveration & .01 & .00 & $.26^{* * *}$ & .19 \\
\hline Sensory sensitivity & -.00 & .00 & -.06 & -.06 \\
\hline Emotional reactivity & .01 & .00 & $.28^{* * *}$ & .18 \\
\hline Endurance & -.00 & .00 & -.03 & -.02 \\
\hline Activity & .01 & .00 & $.15^{* * *}$ & .14 \\
\hline \multicolumn{5}{|l|}{ TEMPS-A: Hyperthymic } \\
\hline Briskness & .00 & .00 & $.09^{*}$ & .07 \\
\hline Perseveration & .00 & .00 & .04 & .03 \\
\hline Sensory sensitivity & .00 & .00 & .02 & .02 \\
\hline Emotional reactivity & -.01 & .00 & $-.27^{* * *}$ & -.17 \\
\hline Endurance & .00 & .00 & .03 & .02 \\
\hline Activity & .02 & .00 & $.50^{* * *}$ & .45 \\
\hline \multicolumn{5}{|l|}{ TEMPS-A: Irritable } \\
\hline Briskness & -.00 & .00 & -.07 & -.05 \\
\hline Perseveration & .00 & .00 & $.11^{*}$ & .08 \\
\hline Sensory sensitivity & -.00 & .00 & -.06 & -.05 \\
\hline Emotional reactivity & .01 & .00 & $.17^{* *}$ & .11 \\
\hline Endurance & .00 & .00 & .03 & .02 \\
\hline Activity & .00 & .00 & .02 & .02 \\
\hline \multicolumn{5}{|l|}{ TEMPS-A: Anxious } \\
\hline Briskness & -.00 & .00 & $-.08^{*}$ & -.06 \\
\hline Perseveration & .01 & .00 & $.26^{* * *}$ & .19 \\
\hline Sensory sensitivity & -.00 & .00 & -.04 & -.03 \\
\hline Emotional reactivity & .02 & .00 & $.41^{* * *}$ & .26 \\
\hline Endurance & -.00 & .00 & -.02 & -.02 \\
\hline Activity & -.00 & .00 & -.03 & -.02 \\
\hline
\end{tabular}


to confirm the theoretical assumption of an overlap between these two concepts of temperament.

Correlations between the temperament scales were consistent with theoretical considerations. The highest positive correlation was observed between ER and PE and anxious, cyclothymic, depressive and irritable temperaments. Given that ER and PE play a similar role as neuroticism (Strelau, 2008; Kandler et al., 2012), these results are not surprising. They are consistent with the results of Blöink et al. (2005), who found positive correlations between neuroticism as measured by the NEO-FFI and all the affective temperaments, except hyperthymic. These positive correlations suggest that the aforementioned temperament dimensions are likely to have a common biological substrate (Oniszczenko \& Dragan, 2014; Vázquez \& Gonda, 2013) and may play a similar role in psychopathology. On the other hand, anxious and depressive temperaments were negatively correlated with BR, EN and AC (no correlation between AC and cyclothymic and irritable temperaments). Hyperthymic temperament was positively correlated with BR, $\mathrm{EN}$ and AC and negatively correlated with ER and PE. These results are in line with findings suggesting that $\mathrm{BR}, \mathrm{EN}$ and $\mathrm{AC}$ are phenotypically and genetically correlated with extraversion (Kandler et al., 2012). In a recent study, Watson, Stasik, Ellickson-Larew and Stanton (2015) showed that in general extraversion is negatively correlated with psychopathology, but some lower order facets of extraversion may be positively related to psychopathology, including bipolar disorder. Thus, high levels of BR, EN and AC can serve as protective buffers against affective disorders, while extremely low levels of these traits may contribute to psychopathology if ER and PE levels are simultaneously high. This hypothesis is consistent with Akiskal and Akiskal's (2005) suggestion that temperament per se has adaptive attributes but its extreme manifestations resulting from gene expression may underlie major mental disorders (see also Akiskal \& Akiskal, 2007; Rihmer et al., 2010). SS as an RTT trait was correlated only with hyperthymic temperament. Although SS tended to reduce trauma symptom intensity in HIV+ individuals (Rzeszutek et al., 2012), the role of SS as a predictor of medical outcomes is quite unclear.

RTT traits as measured by FCB-TI were able to predict affective temperaments to a small extent. Each temperament was predicted by a special pattern of FCB-TI dimensions, with one or two factors being dominant. Four TEMPS-A temperaments (i.e. depressive, cyclothymic, irritable and anxious) were predicted best by ER or by ER and PE together. These traits explained variance from $2 \%$ in the case of irritable temperament to $24 \%$ in the case of anxious temperament. Hyperthymic temperament variance was explained mainly by AC (which accounted for $25 \%$ of the variance of hyperthymic temperament).
The overlap between ER and PE on the one hand and depressive, cyclothymic, irritable and anxious temperaments on the other is consistent with RTT assumptions. ER reveals itself in the intensity of emotional reactions to stimuli, and PE is expressed in the persistence of emotional states. Therefore, both traits contribute significantly to the regulation of human emotions and their consequences, including the risk of developing an affective disorder (Strelau, 2008). AC also explained $4 \%$ of variance in depressive temperament (low level of AC is associated with high level of depressive temperament) as well as $2 \%$ of variance in cyclothymic temperament (high level of AC is correlated with high level of cyclothymic temperament). ER explained 7\% of variance in hyperthymic temperament (low ER level is associated with high level of hyperthymic temperament). The aforementioned results on AC and ER and its associations with depressive, cyclothymic and hyperthymic temperaments are consistent with Akiskal and Mallya's description of affective temperaments (Rovai et al., 2013).

With regard to gender differences both in TEMPS-A and FCB-TI scales, women had higher levels of depressive, cyclothymic and anxious temperaments than men. Women also showed a lower level of hyperthymic temperament than men (no significant difference between the two groups with regard to irritable temperament). These results are similar to the data obtained in TEMPS-A validation studies involving Polish (Borkowska et al., 2010) and German (Blöink et al., 2005) samples. Both the samples consisted of students aged 18 to 47 years, while our sample consisted of people randomly selected from the general population aged from 17 to 69 years. In all the three groups women outnumbered men. Similarly, in all three samples, men scored significantly higher than women on hyperthymic temperament, and women scored significantly higher than men on anxious temperament.

As expected, women had higher levels of PE, SS and ER than men, as well as a lower level of EN than men. No significant differences were found between the two groups with regard to BR and AC. It is noteworthy that women had lower levels of BR and AC compared to men in the non-clinical Polish population (Zawadzki \& Strelau, 1997). In general, two RTT traits significant for affective temperaments, ER and $\mathrm{PE}$, are higher in women than in men. The direction of the gender differences was generally consistent with the data obtained from other studies involving non-clinical populations in different countries (Vázquez et al., 2012).

In summary, a number of reasons support the idea that affective temperaments coincide with the RTT. The RTT is much broader than the concept of affective temperaments, and temperament, according to the RTT, is hypothesised to play an active regulating role between individuals and the external world, 
especially in stressful situations (Strelau, 2008). Two traits postulated by the RTT, ER and PE, may contribute to the development of psychopathology, but in this respect Akiskal's affective temperament concept is more specific.

This study is not without limitations. First, we did not control for the mental health status of participants. Second, a relative over-representation of women was observed in the studied group. The sample was also heterogeneous with regard to age.

\section{CONCLUSIONS}

In conclusion, the results highlight the importance of two RTT traits: ER and PE. They may share similarities with certain affective temperaments and may also contribute to development of affective disorders.

\section{ACKNOWLEDGEMENTS}

This research was supported by a grant from the University of Warsaw (BST No. 1712-10-2014 and partially BST No. 1777-01-2016). The authors declare that they have no conflict of interest.

\section{REFERENCES}

Akiskal, K. K., \& Akiskal H. S. (2005). The theoretical underpinnings of affective temperaments: Implications for evolutionary foundations of bipolar disorder and human nature. Journal of Affective Disorders, 85, 231-239. doi: 10.1016/j. jad.2004.08.002

Akiskal, H. S., \& Akiskal, K. K. (2007). In search of Aristotle: temperament, human nature, melancholia, creativity and eminence. Journal of Affective Disorders, 100, 1-6. doi: 10.1016/j.jad.2007.04.013

Akiskal, H. S., Akiskal, K. K., Haykal, R. F., Manning, J. S., \& Connor, P. D. (2005). TEMPS-A: Progress towards validation of a self-rated clinical version of the Temperament Evaluation of the Memphis, Pisa, Paris, and San Diego Autoquestionnaire. Journal of Affective Disorders, 85, 3-16. doi: 10.1016/j.jad.2004.12.001

Akiskal, H. S., Mendlowicz, M. V., Jean-Louis, G., Rapaport, M. H., Kelsoe, J. R., Gillin, J. C., \& Smith, T. L. (2005). TEMPS-A: Validation of a short version of a self-rated instrument designed to measure variations in temperament. Journal of Affective Disorders, 85, 45-52. doi: 10.1016/j.jad.2003.10.012

Amann, B., Mergl, R., Torrent, C., Perugi, G., Padberg, F., El-Gjamal, N., \& Laakmann, G. (2009). Abnormal temperament in patients with morbid obesity seeking surgical treatment. Journal of Affective Disorders, 118, 155-160. doi: 10.1016/j. jad.2009.01.020
Blöink, R., Briegera, P., Akiskal, H. S., \& Marneros, A. (2005). Factorial structure and internal consistency of the German TEMPS-A scale: Validation against the NEO-FFI questionnaire. Journal of Affective Disorders, 85, 77-83. doi: 10.1016/S01650327(03)00101-0

Borkowska, A., Bieliński, M., Szczęsny, W., Szwed, K., Tomaszewska, M., Kałwa, A., Lesiewska, N., Junik, R., Gołębiewski, M., Sikora, M., Tretyn, A., Akiskal, K., \& Akiskal, H. (2015). Effect of the 5-HTTLPR polymorphism on affective temperament, depression and body mass index in obesity. Journal of Affective Disorders, 184, 193-197. doi: 10.1016/j.jad.2015.05.061

Borkowska, A., Rybakowski, J. K., Drożdż, W., Bieliński, M., Kosmowska, M., Rajewska-Rager, A., Bucinski, A., Akiskal, K. K., \& Akiskal, H. S. (2010). Polish validation of the TEMPS-A: The profile of affective temperaments in a college student population. Journal of Affective Disorders, 123, 36-41. doi: 10.1016/j.jad.2009.09.024

DeGeorge, D. P., Walsh, M. A., Barrantes-Vidal, N., \& Kwapil, T. R. (2014). A three-year longitudinal study of affective temperaments and risk for psychopathology. Journal of Affective Disorders, 164, 94-100. doi: 10.1016/j.jad.2014.04.006

Dembińska-Krajewska, D., \& Rybakowski, J. (2014). The Temperament Evaluation of Memphis, Pisa and San Diego Autoquestionnaire (TEMPS-A) - An important tool to study affective temperaments. Psychiatria Polska, 48, 261-276.

Dembińska-Krajewska, D., \& Rybakowski, J. K. (2015). Psychotropic drugs and personality changes: A case of lithium. Pharmacological Reports, 67, 1204-1207. doi: 10.1016/j.pharep.2015.05.006

Dragan, W. L., \& Oniszczenko, W. (2005). Polymorphisms in the serotonin transporter gene and their relationship to temperamental traits measured by the Formal Characteristics of Behavior Temperament Inventory: Activity and emotional reactivity. Neuropsychobiology, 51, 269-274. doi: $10.1159 / 000085823$

Dragan, W. Ł., \& Oniszczenko, W. (2006). Association of a functional polymorphism in the serotonin transporter gene with personality traits in females in a Polish population. Neuropsychobiology, 54, 45-50. doi: 10.1159/000095741

Dragan, W. Ł., Oniszczenko, W., Czerski, P. M., \& Dmitrzak-Węglarz, M. (2012). Dopamine genes and sensory sensitivity as a temperamental trait. A family-based association study. Journal of Individual Differences, 33, 205-211. doi: 10.1027/16140001/a000069

Fruehstorfer, D. B., Veronie, L., Cremeans-Smith, J. K., \& Newberry, B. H. (2012). Predicting illness-related outcomes with the FCB-TI trait pairs. Examining the nonadditive effects of FCB-TI perseveration. Journal of Individual Differences, 33, 248-256. doi: 10.1027/1614-0001/a000070 
Harnic, D., Pompili, M., Mazza, M., Innamorati, M., Di Nicola, M., Catalano, V., Bruschi, A., Del Bono, D., Forte, A., Lester, D., Girardi, P., Bria, P., \& Janiri, L. (2013). Affective temperaments and psychopathological dimensions of personality in bipolar and cyclothymic patients. Behavioral Medicine, 39, 17-23. doi: 10.1080/08964289.2012.713043

Hornowska, E. (2011). Cloninger's Psychobiological Model of Personality and Strelau's Regulative Theory of Temperament - Analysis of their associations in a Polish sample. Polish Psychological Bulletin, 42, 71-80. doi: 10.2478/v10059-011-0011-0

IBM Corp. (2013). IBM SPSS Statistics for Windows, Version 22.0. Armonk, NY: IBM Corp.

Kandler, C., Held, L., Kroll, C., Bergeler, A., Riemann, R., \& Angleitner, A. (2012). Genetic links between temperamental traits of the regulative theory of temperament and the big five. Journal of Individual Differences, 33, 197-204. doi: 10.1027/1614-0001/a000068

Kawamura, Y., Akiyama, T., Shimada, T., Minato, T., Umekage, T., Noda, Y., Ukawa, K., Hashidume, C., Sakai, Y., Otowa, T., Sasaki, T., \& Akiskal, H. S. (2010). Six-year stability of affective temperaments as measured by TEMPS-A. Psychopathology, 43, 240-247. doi: 10.1159/000313522

Khazaal, Y., Gex-Fabry, M., Nallet, A., Weber, B., Favre, S., Voide, R., Zullino, D., \& Aubry, J. M. (2013). Affective temperaments in alcohol and opiate addictions. Psychiatric Quarterly, 84, 429-438. doi: 10.1007/s11126-013-9257-3

Kwapil, T. R., DeGeorge, D., Walsh, M. A., Burgin, C. J., Silvia, P. J., \& Barrantes-Vidal, N. (2013). Affective temperaments: Unique constructs or dimensions of normal personality by another name? Journal of Affective Disorders, 151, 882-890. doi: 10.1016/j. jad.2013.07.028

Oniszczenko, W., \& Dragan, W. L. (2005). Association between dopamine D4 receptor exon III polymorphism and emotional reactivity as a temperamental trait. Twin Research and Human Genetics, 8, 633-637. doi: 10.1375/twin.8.6.633

Oniszczenko, W., \& Dragan, W. Ł. (2006). Struktura temperamentu $w$ ujęciu regulacyjnej teorii temperamentu a polimorfizmy w genach 5-HTT, DAT1 i DRD4 u młodych kobiet [The structure of the temperament postulated in the Regulative Theory of Temperament and polymorphisms in the 5-HTT, DAT1 and DRD4 genes in young females]. Neuropsychiatria i Neuropsychologia, 1, 24-30.

Oniszczenko, W., \& Dragan, W. Ł. (2012). Association between temperament in terms of the Regulative Theory of Temperament and DRD4 and DAT1 gene polymorphisms. Comprehensive Psychiatry, 53, 789-796. doi: 10.1016/j.comppsych.2012.01.001

Oniszczenko, W., \& Dragan W. Ł. (2014). From twins to genetic polymorphisms: Behavioural genetic research in Poland. Twin Research and Human Genetics, 17, 390-396. doi: 10.1017/thg.2014.45

Oniszczenko, W., Dragan, W., Chmura, A., \& Lisik, W. (2015). Temperament as a risk factor for obesity and affective disorders in obese patients in a Polish sample. Eating and Weight Disorders - Studies on Anorexia, Bulimia and Obesity, 20, 233-239. doi: 10.1007/s40519-014-0151-2

Oniszczenko, W., \& Laskowska, A. (2014). Emotional reactivity, coping style and cancer trauma symptoms. Archives of Medical Science, 10, 110-116. doi: 10.5114/aoms.2013.33069

Oniszczenko, W., Rybakowski, J., Dragan, W. Ł., Grzywacz, A., \& Samochowiec, J. (2015). The ADH gene cluster SNP rs1789891 and temperamental dimensions in patients with alcohol dependence and affective disorders. Scandinavian Journal of Psychology, 56, 420-427. doi: 10.1111/sjop.12223

Oniszczenko,W., Zawadzki, B., Strelau, J., Riemann, R., Angleitner, A., \& Spinath, F. M. (2003). Genetic and environmental determinants of temperament: A comparative study based on Polish and German samples. European Journal of Personality, 17, 207-220. doi: 10.1002/per.472

Pompili, M., Pennica, A., Serafini, G., Battuello, M., Innamorati, M., Teti, E., Girardi, N., Amore, M., Lamis, D. A., Aceti, A., \& Girardi, P. (2013). Depression and affective temperaments are associated with poor health-related quality of life in patients with HIV infection. Journal of Psychiatric Practice, 19, 109-117. doi: 10.1097/01.pra.0000428557.56211

Rezvani, A., Aytüre, L., Arslan, M., Kurt, E., EroğluDemir, S., \& Karacan, i. (2014). Affective temperaments in patients with rheumatoid arthritis. International Journal of Rheumatic Diseases, 17, 34-38. doi: 10.1111/1756-185X.12033

Rihmer, Z., Akiskal, K. K., Rihmer, A., \& Akiskal, H. S. (2010). Current research on affective temperaments. Current Opinion in Psychiatry, 23, 12-18. doi: 10.1097/YCO.0b013e32833299d4

Ristić-Ignjatović, D., Hinić, D., Bessonov, D., Akiskal, H. S., Akiskal, K. K., \& Ristić, B. (2014). Towards validation of the short TEMPS-A in non-clinical adult population in Serbia. Journal of Affective Disorders, 164, 43-49. doi: 10.1016/j. jad.2014.04.005

Rovai, L., Maremmani, A. G., Rugani, F., Bacciardi, S., Pacini, M., Dell'Osso, L., Akiskal, H. S., \& Maremmani, I. (2013). Do Akiskal \& Mallya's affective temperaments belong to the domain of pathology or to that of normality? European Review for Medical and Pharmacological Science, 17, 2065-2079.

Rózsa, S., Rihmer, Z., Gonda, X., Szili, I., Rihmer, A., Kő, N., Németh, A., Pestality, P., Bagdy, G., Alhassoon, O., Akiskal, K. K., \& Akiskal, H. S. (2008). A study of affective temperaments in Hungary: Internal consistency and concurrent validity of the TEMPS-A against the TCI and NEO-PI-R. 
Journal of Affective Disorders, 106, 45-53. doi: 10.1016/j.jad.2007.03.016

Rybakowski, J. K., Dembińska, D., Kliwicki, S., Akiskal, K. K., \& Akiskal, H. H. (2013). TEMPS-A and long-term lithium response: Positive correlation with hyperthymic temperament. Journal of Affective Disorders, 145, 187-189. doi: 10.1016/j. jad.2012.07.028

Rybakowski, J. K., Dmitrzak-Weglarz, M., Dembińska-Krajewska, D., Hauser, J., Akiskal, K. K., \& Akiskal, H. H. (2014). Polymorphism of circadian clock genes and temperamental dimensions of the TEMPS-A in bipolar disorder. Journal of Affective Disorders, 159, 80-84. doi: 10.1016/j. jad.2014.02.024

Rybakowski, J. K., Kamińska, K., Charytonik, J., Akiskal, K. K., \& Akiskal, H. S. (2014). Temperamental dimensions of the TEMPS-A in females with co-morbid bipolar disorder and bulimia. Journal of Affective Disorders, 164, 90-93. doi: 10.1016/j.jad.2014.04.016

Rzeszutek, M., Oniszczenko, W., \& Firląg-Burkacka, E. (2012). Temperament traits, coping style and trauma symptoms in $\mathrm{HIV}_{+}$men and women. AIDS Care, 24, 1150-1154. doi: 10.1080/09540121.2012.687819

Rzeszutek, M., Oniszczenko, W., Schier, K., BiernatKałuża, E., \& Gasik, R. (2015). Trauma symptoms, temperament traits, social support and the intensity of pain in a Polish sample of patients suffering from chronic pain. Personality and Individual Differences, 83, 13-17. doi: 10.1016/j.paid.2015.03.036

Siwek, M., Dudek, D., Drozdowicz, K., Jaeschke, R., Styczeń, K., Arciszewska, A., Akiskal, K. K., Akiskal, H. S., \& Rybakowski, J. K. (2015). Temperamental dimensions of the TEMPS-A in male and female subjects engaging in extreme or/and high risk sports. Journal of Affective Disorders, 170, 66-70. doi: 10.1016/j.jad.2014.08.036

Strelau, J. (1996). The regulative theory of temperament: Current status. Personality and Individual Differences, 2, 131-142. doi: 10.1016/01918869(95)00159-X

Strelau, J. (1998). Temperament: A psychological perspective. New York: Plenum Press.

Strelau, J. (2008). Temperament as a regulator of behavior. After fifty years of research. New York: Werner.

Strelau, J., \& Zawadzki, B. (1995). The Formal Characteristics of Behavior - Temperament Inventory (FCB-TI): Validity studies. European Journal of Personality, 9, 207-229. doi: 10.1002/per.2410090304

Tabachnick, B. G., \& Fidell, L. S. (2013). Using multivariate statistics $\left(6^{\text {th }}\right.$ ed.). Boston, MA: Pearson.

Vázquez, G. H., \& Gonda, X. (2013). Affective temperaments and mood disorders: A review of current knowledge. Current Psychiatry Reviews, 9, 21-32. doi: $10.2174 / 157340013805289617$
Vázquez, G. H., Tondo, L., Mazzarini, L., \& Gonda, X. (2012). Affective temperaments in general population: A review and combined analysis from national studies. Journal of Affective Disorders, 139, 18-22. doi: 10.1016/j.jad.2011.06.032

Watson, D., Stasik, S. M., Ellickson-Larew, S., \& Stanton, K. (2015). Extraversion and psychopathology: A facet-level analysis. Journal of Abnormal Psychology, 124, 432-446. doi: 10.1037/abn0000051

Zawadzki, B., \& Strelau, J. (1997). Formalna Charakterystyka Zachowania-Kwestionariusz Temperamentu (FCZ-KT). Podręcznik [The Formal Characteristics of Behavior - Temperament Inventory (FCB-TI). Manual]. Warszawa: Pracownia Testów Psychologicznych Polskiego Towarzystwa Psychologicznego. 